\title{
Textual Notes on the Latin Odes of Garcilaso de la Vega
}

\author{
Jay Reed \\ Brown University \\ Joseph_Reed@brown.edu
}

Recepción: 20/04/2021, Aceptación: 13/05/2021, Publicación: 22/12/2021

\section{Resumen}

Se ofrecen notas críticas sobre el texto de las odas latinas de Garcilaso de la Vega.

Palabras clave

Garcilaso de la Vega; poesía neolatina; crítica textual.

\author{
Abstract \\ Textual criticism of passages in the Latin odes of Garcilaso de la Vega. \\ Keywords \\ Garcilaso de la Vega; Neolatin poetry; textual criticism.
}


Three Latin odes by the Spanish poet Garcilaso de la Vega have come to light, each composed in the lyric meters of Horace's Odes, apparently during Garcilaso's service in Naples (1532-1535). ${ }^{1}$ A thorough critical edition of the three poems is needed, especially given the occasional typographical errors, inconsistencies, and other problems that mar the available editions, and the research project Garcilaso de la Vega en Italia headed by Prof. Eugenia Fosalba (website at https://pronapoli.com $)^{2}$ is assembling the materials that will make one possible. The present notes are intended to aid the discussion and clarification of some problem passages.

All three poems originally circulated in manuscript copies at an indeterminate remove from Garcilaso's originals, and copyists' errors are unsurprisingly evident. Our primary source for Odes I and $\mathrm{III}^{3}$ is Neapolitanus Bibl. Nat. XIII AA 63 (respectively on fol. 62r-63r and 58r-60r), a collection of texts in different hands from the circle of the brothers Antonio and Girolamo Seripando, on which see Fosalba (2019: 50-79) and in Fosalba and Torre (2018: 297-321). I cite readings of this ms. from the digital images that are available at https:// pronapoli.com/biblioteca-digital. ${ }^{4}$ The copies of Odes I and III in Vaticanus Lat. 2836 (respectively on fol. $260 v-261 v$ and $259 r-260 r$ ) and of Ode III in Neapolitanus Bibl. Nat. V E 53 (fol. $47 r-48 v$ ) are thought to derive from those in the Seripando archive (Fosalba 2019: 53 and in Fosalba and Torre 2018: 17). Ode II has a separate transmission in Biblioteca Nacional de Madrid MSS/5785 fol. $272 r^{5}$

Garcilaso is also known to have written other Latin poetry. Cardinal Bembo, in letters of August 1535 to the Benedictine monk Onorato Fascitelli and to Garcilaso, singles out for praise an otherwise unknown Latin ode of Garcilaso's addressed to Bembo himself; ${ }^{6}$ Fosalba speculates that Bembo kept that ode in

1. On this period of Garcilaso's literary career see Keniston (1925: 117-128), Chinchilla (2010), Furstenberg-Levi (2016), Fosalba and Torre (2018), Fosalba (2019).

2. Accessed 5 April 2021, "Garcilaso de la Vega en Italia. Clasicismo horaciano (20202024)" Ministerio de Ciencia e Innovación. PID2019-107928GB-100. The most recent published editions are Morros's major and minor (1995, 2007) and Alcina (2011), first published in 1989-none solidly based on the mss. For the Latin odes Morros relies on the editorial work of Alcina and of María Ángeles Villalonga (Morros 1995: cxv). Alcina in turn relies on Rivers (1974: 459-483) and (for Ode I) Perosa and Sparrow (1979: 521-524), as well as on Luque (1979) (see Alcina 2011:60), while those editors evidently rely for their knowledge of the mss. on earlier editors (Luque 1979: 304) emphasizes the provisionality of his critical notes).

3. I follow the numbering used in the most recent editions.

4. Accessed 5 April 2021.

5. For the readings of the three last-named mss. I rely on digital scans kindly provided by Prof. Fosalba. I am also grateful to her and to Prof. Juan Alcina for other points of information and references.

6. Travi (1992: 608) (“... a me pare che l'oda, che egli a me scrive, sia eziandio più vaga e elegante e monda e sonora e dolce, che le altre tutte non sono che in que' fogli sono") and 612 ("Ex iis car- 
his own possession, while sending back to Naples the two that are preserved there (I and III). ${ }^{7}$ Also ascribed to Garcilaso is a Latin epigram addressed to Hernando de Acuña (last printed with Garcilaso's work in Gallego 1972: 251), on whose authorship see the opposing views of Keniston (1922: 270-273) (against) and Pascual Barea 2002 (for). Fosalba (2016: 407) n. 43 (cf. 387-388 and 2019: 62-79) raises, but prudently declines to decide on, Garcilaso's authorship for an anonymous Latin iambic poem and a Greek epigram on the death of Ariosto included in the Seripando collection in Naples.

\section{Ode I}

The poem, on Garcilaso's recent exile and the intellectual comforts that Naples offers him, is addressed to the Italian humanist Antonio Telesio, himself a Latin poet. In both the Naples and Vatican mss. it bears the title Ode Tricolos tetrastrophos Ad Thylesium (referring to its Alcaic meter). Alone of the three odes it met with publication before the late 1890s: the editio princeps was in Daniele's edition of Telesio, where it is titled Garcilassi de Vega Toletani ad Antonium Thylesium ode (Daniele 1762: 128-9). ${ }^{8}$ The poem was reedited by Savj-López and Mele 1897 (evidently from Daniele) on a suggestion by Cian (1894: 409) (cf. Mele 1924: 43); Mele (1924) is aware of the readings of the Naples and Vatican mss. (through the aid, he says, of Nicola Festa). On the interrelations between Garcilaso and Telesio and their literary outputs see Fosalba (2012) and Alejandro Coroleu in Fosalba and Torre (2018).

5-6 The whole sentence should run, "I have now learned under constraint to endure the arrogance and haughty manner of the [German] barbarians and to lighten my grievances among the pathless rocks ... under the hoarse noise of the Danube." Both mss. (as well as Daniele) have iam didici, et invia / per saxa, which is unmetrical, et being the stumbling block. Savj-López and Mele (1897) delete et and print invia alone (cf. Keniston 1925: 298); Luque (1979: 305) offers the explanation that $e t$ was introduced by a copyist who misunderstood the syntax: he takes ferre (4, "endure") as depending on coactus (literally "forced"), with the independent clause confined to didici ... levare (5-8, "I have learned to lighten ...”). I suspect rather that a copyist regularized the word order

minibus, quae ad me pridem scripsisti, et quantum me amares libentissime perspexi ... et quantus ipse esses in lyricis pangendis, quantumque praestares ingenii luminibus ... facile cognovi”).

7. Fosalba in Fosalba and Torre (2018: 19-20) n. 2; cf. Morros (1995: 245-246), Fosalba (2018).

8. An early 19th c. copy of Daniele's edition with Spanish translation by D. Fernando de la Serna y Santander is preserved in Biblioteca Nacional de Madrid MSS/21291/7 pp. 1-8; it contains occasional corrections that usually correspond to later printed editions (e.g. 19 gestit). I owe my knowledge of this copy-which should be of interest for the history of the reception of these odes - to an anonymous reader for the Journal and to Prof. Fosalba. 
of a postponed $e$, and I would follow Mele (1924: 43) in restoring invia et: both ferre and levare are dependent on didici, with et coordinating them and with coactus in a predicate construction (tantamount to "under constraint").

18-19 aureo / nodare nexu gestit. "[the city that the river Tagus] longs to tie up in a golden bow." In the Naples ms. the vowel in the verb ending could be a very narrow $a$ or an $i$ without a dot (not normal in this ms.); the Vaticanus has gestat, as does Daniele. That verb does not take an infinitive in any sense, and Savj-López and Mele (1897) correctly print gestit.

22 cultoque pulchra Parthenope solo: "And in lovely Naples with its cultivated soil"? The combination of the two ablatives in the mss. is awkward, and one might suspect an error for genitive pulchre Parthenope (i.e. -ae ... -ae) or pulchre Parthenopes, "on the cultivated ground of lovely Naples." Daniele interprets the ms. reading as pulchra Parthenopae.

23 The unmetrical considerre ("sit") of the mss. may be Garcilaso's own error, but Keniston (1925: 299) posited a miscopying of the synonymous consědère, a compound verb that, "[a]lthough ... not found in Classic Latin," occurs in the Vulgate.

41 The mss. have carmen canentis sic animus rapit / mentemque ("the spirit of the one singing so seizes the song and mind ..."), where the accusative animum printed by editors since Savj-López and Mele (1897) makes far better sense: "as he sings [of the aforesaid myths], his song so seizes [my] spirit and mind ....". An anonymous reader for the Journal nicely suggests the accusative plural animos, which is paleographically closer. The accusatives in the foregoing stanza (referring to the themes of Telesio's Imber Aureus, on the myth of Danaë) are the objects of canentis.

\section{Ode II}

This shortest of the odes, addressed to Juan Ginés de Sepúlveda (whose Democrates, advancing arguments for the propriety of religious war, appeared in 1535), and looking forward to his history of Charles V's African campaign, shifts from wonderment at its addressee's militant theology to a vivid image of the emperor driving his Tunisian enemies before him (on the imagery and its intertexts see Cruz 2002: 198, Gray 2016). First printed by Bonilla (1899), it was preserved in a Madrid ms., unlike the other two odes (see above); there it bears the title Garsice Lasi Ode ad se Genesium Sepuluedam. Garcilaso himself may have conveyed it to Sepúlveda at the same time he did a copy of Luis de Ávila y Zúñiga's Historia de la campaña de Túnez (cf. Sepúlveda's letter of January 1536 discussed by Keniston 1922: 139-140).

18-20 The ms. reads Giro, sauus uti Maßylas leo / Per syluas; Nomadasue I Imbelles agitat feras. Keniston (1925: 215), emending the toponyms, corrected this to Gyro, saevus uti Massylias leo / Per sylvas Numidasve ... : "[Charles 
drives his enemies] in a circle, just as through the forests of Marseille or Numidia a lion chases timid beasts." His Massylias is a loaded term, as my translation suggests through its anomalousness: as referring to the ancient Massylian (Massȳlii) people of Numidia-immediately apt in sense because, of course, lions are found in Africa ${ }^{9}$ - it is unmetrical (like the manuscript's synonymous Massylas), ${ }^{10}$ since a choriamb-shaped word is required; as evoking Marseilles (Latin Massilia), which does not actually sustain lions, ${ }^{11}$ it scans correctly and points to a different sphere of Charles's military aspirations (Garcilaso was to receive his mortal wound in Charles's service on the road between Marseilles and Nice). The philological dilemma posed here forces us to consider a wider imperial program.

Editors, starting with Bonilla, report Homadasue in 19. The initial letter in the ms. looks to me more like $N$ (compare the $H$ at the opening of 31 , with its straighter horizontal); in any case Keniston is right to read a word for "Numidian." The terms Nomadas (printed by Mele 1924) and Numidas are equivalent toponyms in this context, but according to Latin norms only the latter is suitable as an adjective with sylvas (see OLD s.v. Nomades 1a and Numida c).

34-5 Here the metrical problem is the converse of that of ms. Massylas in 18. The ms. reads non ferat indidem / ingeneretque furorem ("would not bring and generate rage out of that place [i.e. the womb whence Charles was putatively torn by Caesarean section]"). The prosody of ingĕnĕretque (where the opening of this pherecratean requires three long syllables, no resolution permitted) is sufficient to condemn the reading, even were the coupling of the verbs not jejune. Mele (1924) is doubtless right to posit a scribal error for ingentemque furorem: "would not bring out of there both an immense rage [and a thirst for hot bloodshed]."

\section{Ode III}

The text was first printed by Mele (1898), who cites Neapolitanus Bibl. Nat. V E 53; by (1924: 45-48) he is aware of the primary Naples ms., XIII AA 63. This ode (untitled in the mss.) is unusual in that it is a third-person narrative of a confrontation between the deities of love, Venus and Cupid. In fact the dialogue between them that dominates the poem, occupying all but the introductory thirteen lines and the two-word transition between speakers at 62 (ait puer,

9. Cf. the "lion in Punic fields" (Poenorum ... in arvis ... leo) that figures in a simile in Virgil, Aeneid 12.4-6 and the "Numidian lions" (Numidasque leones) in Ovid, Ars Amatoria 2.183.

10. The Massylius of Mele 1924, modifying leo, reflects a misunderstanding of the syntax.

11. Note, however, that a lion figured on the ancient coinage and later heraldry of the citywhich sits on the Gulf of Lion. 
"said the boy"), constitutes a close versification of Lucian's Dialogues of the Gods $20,{ }^{12}$ based on the Latin prose translation by Erasmus, ${ }^{13}$ a model that can inform our decisions about the text (see on 52-53).

3 thure altaria sacro, "altars [smoldering] with holy frankincense." This line-being a pherecratean, whereas other odd-numbered lines in this poem are glyconics - is one syllable short. Luque (1979: 299), in saying that in the line, "además del hiato, tendríamos una segunda sílaba breve," is evidently scanning it as a crude glyconic, thürĕ altăriā săcro. Garcilaso is most unlikely to have perpetrated such a plethora of prosodic solecisms (cretic line opening, hiatus, -tăr-, nominative plural in $-\bar{a}$ ). The evidence of the rest of the poem shows him well able to compose a glyconic, and we should certainly assume a lacuna, ${ }^{14}$ with text of a syllable (or two, in the case of elision) accidentally left uncopied: thure altaria $<\ldots>$ sacro. An adverb "there," specifying the Cypriot setting indicated in the opening line (sedes ad Cyprias), would be welcome (e.g. ibì). In line 44 editors accept the cumque ignes ("and when the fires [of love]") first printed by Mele (1898: 365) for ms. cum ignes, which through elision would otherwise leave the colon one syllable short (see Luque 1979: 309).

On a kindred lapse: in the evident lacuna at the opening of an epitaph on Garcilaso, possibly by Bembo, printed from a British Library ms. by López Grigera (1988: 306) (cf. 296), I would venture to posit a term for the love goddess, balancing the personification in Marte and completing a thematic polarity favored by Garcilaso himself (as in e.g. his Ode ad florem Gnidi): <Cypride> lassus erat, nunc clarus Marte quiescit ("he had been worn out by Love; now he reposes illustrious in War").

5 gaudebat, cum puer appulit, "[Venus] was taking joy [in dancing], when her boy approached." This odd-numbered line, conversely, has one long syllable too many. Emendation of the imperfect gaudebat ${ }^{15}$ to gaudet, an unremarkable historical present (like incipit in 13), would repair the meter, and Luque (1979: 308) (who also conjectures the unmetrical gaudebat, puer cum appulit, but ultimately considers neither solution "absolutamente justificable") very plausibly suggests that a copyist made the reverse substitution.

30 The Clymene' of the mss. (in the Vaticanus, Clymene) should be interpreted as the normal Latinized Greek first-declension acc. form Clymenen (as in

12. Critical text of the Greek in MacLeod (1987: 304-305); for a text with English translation see the Loeb edition (MacLeod 1961: 330-335).

13. Published earliest in Luciani viri quam disertissimi compluria opuscula longe festiuissima ab Erasmo Roterodamo et Thoma Moro interpretibus optimis in latinorum linguam traducta (Paris 1506) fol. L verso; see Czepiel, esp. (2019: 744) n. 31 and (753) n. 50. C. Robinson in ASD (1.1: 585-586) offers a modern edition. On Erasmus' and his collaborator Thomas More's translations of Lucian see Rummel (1985: 49-69).

14. As Christopher Parrott emphasized to me in April 2014.

15. In the Vatican ms. the word looks like gaudibat, but should probably be read as the normal form. 
e.g. Ovid, Metamorphoses 1.756), not a third-declension form Clymenem as commonly printed in editions going back to Mele's editio princeps. In the primary ms. the same symbol can represent syllable-final $m$ or $n$ : for the latter see e.g. lines 16 and 66 non, 22 frontem, 40 long(a)eva, 53 cuncta and omen, etc. Garcilaso's model Erasmus (1506) gives Clymenen.

$52-4$ proin $/<\ldots>$ mater cuncta timens, "So $<\ldots>$ mother, fearing all [these things] ...." These successive ms. lines in Venus' speech are both lesser asclepiads, so a copyist has omitted a whole verse (a glyconic) between them, as Mele (1898: 365) already notes (cf. Gutiérrez 1952: 306 n.). Lucian's original at this

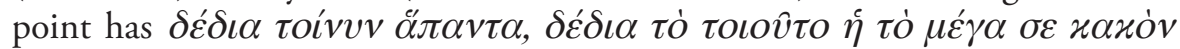
$\dot{\varepsilon} \gamma \dot{\omega} \tau \varepsilon \varkappa o \hat{v} \sigma \alpha$, which Erasmus renders Proinde cuncta timeo. Metuo ne tale quid accidat quandoquidem te produxi, malum ingens ... ("So I fear all [these things]. I am afraid that, since I brought you forth as a great trouble, something like the following may happen ...”). Words corresponding to "since I brought you forth as a great trouble" are lacking in Garcilaso; if we adapt the sense of quandoquidem te produxi, malum ingens to the syntax of Garcilaso's mater and to glyconic meter, we might consider some such supplement as ingentis quia sum mali I mater ("since I am the mother of a great trouble"). ${ }^{16}$

56 In ne fortē Cybele, "lest perchance Cybele ...," the false lengthening seems a rare metrical error on Garcilaso's part, perhaps based on adverbs in $-\bar{e}$ (compare the metrical question raised above on I.23), unless we should posit a scribal misreading of forsan (or Horatian forsit) or omission of some monosyllable like $e t$, with elision. For the restoration of an elided monosyllable compare 1819 , where the mss. show verum etiam deos / ausis stringere spicula ("but you even dare to draw your arrows $<\ldots>$ the gods" ${ }^{17}$ : a preposition meaning "against" seems required, and Mele, first in 1898 (cf. Keniston 1925: 303), prints etiam in deos (the meter is not affected there).

69 adblandirier: So Neapolitanus Bibl. Nat. XIII AA $62^{18}$ and the Vaticanus, correctly (compare Erasmus' adblandiuntur). Some editions (beginning with Mele 1924; Mele 1898 has the nonsensical abblandiries) give ablandirier, the misspelling of Neapolitanus Bibl. Nat. V E 53.

72 quid egō peccŏ tibi aut aliis: The first-person singular ending in $-\breve{o}$ (cf. 74

16. An anonymous reader for the Journal suggests also immanis or inmensi (for my ingentis), noting that they would avoid repetition with ingentique ... voce in line 50 (which is part of an expansion of Erasmus' tumultus).

17. The scansion entailed by -erĕ spi-is mostly alien to classical Latin verse, but occurs in Propertius and Horace's Satires, and once in Virgil (Aeneid 11.309). Cf. Odes I.65 suaderĕ, sperans and II.23 tenderĕ suetae. Garcilaso's frequent elisions, including those of long syllables, also evince a metrical style closer to Horace's Satires than to his Odes. His metrical practice fits within the broad range evinced by Neolatin lyric (on which see Charlet 2020: 151-228).

18. The first $r$, however, does not look like other $r$ in the scan of the ms.; it looks more like an $e$ and may show signs of correction. 
monstrŏque, 84 petŏ; 70 offero and 73 offero occur at line-end and so are indeterminate) is a feature of post-Augustan Latin poetry. The long $-\bar{o}$ in ego is found in ancient Roman comedy and only rarely later ([Virgil], Lydia 53; Valerius Flaccus, Argonautica 8.158); here an editor might be tempted to posit a scribal omission of correlative aut (so quid ego aut ...; see above on 56). But the concentration of un-Horatian features in this line (note also the synizesis in aliis, scanned as aliss) may conceivably involve a knowing metapoetic turn on its sense (Cupid's rhetorical question to Venus, "how am I sinning against you or others?"). 


\section{Works cited}

Alcina, Juan Francisco (ed,), Garcilaso de la Vega: Poesía completa, Madrid, Austral, 2011.

$A S D=$ Opera Omnia Desiderii Erasmi Roterodami, Amsterdam, North-Holland, 1969.

Bonilla y San Martín, Adolfo, "Oda latina de Garci-Lasso de la Vega", Revista Critica de Historia y Literatura españoles, portuguesas, é hispano-americanas, IV (1899), 362-371.

Charlet, Jean-Louis, Métrique latine humaniste. Des pré-humanistes padouans et de Pétrarque au XVI siècle, Geneva, Droz, 2020.

Chinchilla, Rosa Helena, "Garcilaso de la Vega, Catullus, and the Academy in Naples", Caliope, XVI, 2 (2010), 65-81.

Cian, Vittorio, "review of L. Tansillo, L'egloga e i poemetti, con introduzione e note di Francesco Flamini (Naples 1893)", Giornale storico della letterature italiana, XXIV (1894), 405-422.

Cruz, Anne J., "Arms Versus Letters: The Poetics of War and the Career of the Poet in Early Modern Spain”, in European Literary Careers: The Author from Antiquity to the Renaissance, ed. Patrick Cheney and Frederick A. de Armas, Toronto, University of Toronto Press, 2002, 186-205.

Czepiel, Maria, "Garcilaso's 'Sedes ad cyprias': A New Source and a Re-appraisal”, Bulletin of Spanish Studies, XCVI (2019), 737-754.

Daniele, Francesco, Antonii Thylesii Cosentini Opera, Naples, Fratres Simonii, 1762.

Fosalba Vela, Eugenia, "Sobre la relación de Garcilaso con Antonio Tilesio y el círculo de los hermanos Seripando", Cuadernos de Filología Italiana, XIX (2012), 131-144.

—, "Más sobre la estancia de Garcilaso en Nápoles. Epigramas funerales a la muerte de Ariosto", in Rinascimento meridionale. Napoli e il Viceré Pedro de Toledo (1532-1553), ed. Encarnación Sánchez García, Naples, Pironti, 2016, 387-407.

—, "La carta de Bembo a Garcilaso", Insula, núm. 862 (2018), 9-13.

-, Pulchra Parthenope: Hacia la faceta napolitana de la poesía de Garcilaso, Madrid, Iberoamericana-Vervuert, 2019.

—, and Gáldrick de la Torre Ávalos (eds.), Contexto latino y vulgar de Garcilaso en Nápoles, Bern, Peter Lang, 2018.

Furstenberg-Levi, Shulamit, The Accademia Pontaniana: A Model of a Humanist Network, Leiden, Brill, 2016.

Gallego Morell, Antonio, Garcilaso de la Vega y sus comentaristas: Obras completas del poeta, 2nd ed., Madrid, Gredos, 1972.

Gray, Andrew F., "Garcilaso at Home in Naples: On the Neo-Latin Muse of the Príncipe de los Poetas Castellanos", Calíope, XXI (2016), 5-33.

Gutiérrez Volta, Joaquina, "Las odas latinas de Garcilaso de la Vega", Revista de Literatura, II (1952), 280-308. 
Keniston, Hayward, Garcilaso de la Vega: A Critical Study of His Work, New York, Hispanic Society of America, 1922.

—, Garcilaso De La Vega: Works, New York, Hispanic Society of America, 1925.

López Grigera, Luisa, "Notas sobre las amistades italianas de Garcilaso: un nuevo manuscrito de Pietro Bembo", in Homenaje a Eugenio Asensio, ed. Luisa López Grigera y Augustin Redondo, Madrid, Gredos, 1988, 291-309.

Luque Moreno, Jesús, "Las poesías latinas de Garcilaso de la Vega: notas sobre métrica y crítica textual", in Estudios sobre literatura y arte dedicados al profesor Emilio Orozco Díaz, ed. Antonio Gallego Morell, Andrés Soria, and Nicolás Marín, Granada, Universidad de Granada-Facultad de filosofía y letras, 1979, 297-310.

MacLeod, Malcolm D. (ed.), Lucian: Volume VII, Cambridge, MA, Harvard University Press, 1961.

- (ed.), Luciani Opera, IV, Oxford, Oxford University Press, 1987.

Mele, Eugenio, "Una Oda latina inédita de Garcilaso de la Vega y tres poesías inéditas a él dedicadas por Cosimo Anisio", Revista Crítica de Historia y Literatura españoles, portuguesas, é hispano-americanas, III (1898), 362-368.

—, "Las poesías latinas de Garcilaso de la Vega y su permanencia en Italia", part 2, Bulletin Hispanique, XXVI (1924), 35-51.

Morros, Bienvenido (ed.), Garcilaso de la Vega: Obra poética y textos en prosa, Barcelona, Crítica (Biblioteca Clásica), 1995.

- (ed.), Garcilaso de la Vega: Obra poética y textos en prosa, Barcelona, Crítica (Clásicos y Modernos), 2007.

OLD = Oxford Latin Dictionary, ed. P. G. W. Glare, Oxford, Oxford University Press, 1982.

Pascual Barea, Joaquín, "El epigrama latino de Garcilaso de la Vega a Hernando de Acuña: edición crítica y traducción, autoría y comentario literario", in Humanismo y pervivencia del mundo clásico: Homenaje al Profesore Antonio Fontán, III, ed. José María Maestre Maestre, Luis Charlo Brea, Joaquín Pascual Barea, Antonio Fontán Pérez, Madrid, Laberinto, 2002, 1049-1096.

Perosa, Alessandro, and John Sparrow, Renaissance Latin Verse: An Anthology, Chapel Hill, NC, University of North Carolina Press, 1979.

Rivers, Elias L., Garcilaso de la Vega: Obras completas con comentario, Columbus, Ohio State University Press, 1974.

Rummel, Erika, Erasmus as a Translator of the Classics, Toronto, University of Toronto Press, 1985.

Savj-López, Pablo, and Eugenio Mele, "Una Oda latina de Garcilasso de la Vega", Revista Crítica de Historia y Literatura españoles, portuguesas, é hispano-americanas, II (1897), 248-51.

Travi, Ernesto, Pietro Bembo: Lettere, III, Bologna, Commissione per i testi di lingua, 1992. 